\title{
Coat and Enterotoxin-related Proteins in Clostridium perfringens Spores
}

\author{
By SANGRYEOL RYU AND RONALD G. LABBE* \\ Food Microbiology Laboratory, Department of Food Science, University of Massachusetts, \\ Amherst, Massachusetts 01003, USA
}

(Received 5 April 1989; revised 3 July 1989; accepted 7 July 1989)

\begin{abstract}
Coat proteins from mature spores of two enterotoxin-positive $\left(\mathrm{Ent}^{+}\right)$and two enterotoxinnegative (Ent $\left.{ }^{-}\right)$strains of Clostridium perfringens were solubilized using $50 \mathrm{~mm}$-dithiothreitol and $1 \%$ sodium dodecyl sulphate at $\mathrm{pH} 9.7$, and alkylated using $110 \mathrm{~mm}$-iodoacetamide to prevent aggregation. The coat proteins and $C$. perfringens type $A$ enterotoxin (CPE) were separated by SDS-PAGE and analysed by Western blotting using anti-CPE antibody. As previously reported, CPE aggregated in the presence of SDS, but no aggregation occurred at concentrations below $15 \mu \mathrm{g} \mathrm{CPE} \mathrm{ml}{ }^{-1}$. Two CPE-related proteins ( 34 and $48 \mathrm{kDa}$ ) were found in the solubilized spore coat protein of $\mathrm{Ent}^{+}$strains while only the $48 \mathrm{kDa}$ CPE-related protein was found in the spore coat fraction of Ent ${ }^{-}$strains. CPE-related proteins comprised $2.7 \%$ and $0.8 \%$ of the total solubilized coat protein of Ent ${ }^{+}$and $\mathrm{Ent}^{-}$strains respectively. CPE-related proteins could be extracted from the spores with $1 \%$ SDS alone. They could also be released by disruption of whole spores, indicating that the CPE-related proteins may be in the spore core or trapped between the core and coat layers. The results suggest that CPE is not a major structural component of the coat fraction of $C$. perfringens spores.
\end{abstract}

\section{INTRODUCTION}

The bacterial spore coat is a spore-specific constituent and plays an important role in germination, dormancy or resistance (Jenkinson, 1981, 1983; Kutima \& Foegeding, 1987; Labbe et al., 1978; Moir, 1981; Stelma et al., 1980). The spore coat protein comprises $25-80 \%$ $(\mathrm{w} / \mathrm{w})$ of the mature spore and is one of the few sporulation-specific gene products (Keynan $\&$ Sandler, 1983). Depending on the species involved, spore coat protein is composed of one to several structurally different polypeptides (Aronson \& Fitz-James, 1976; Goldman \& Tipper, 1978; Jenkinson et al., 1981; Munoz et al., 1978; Stewart \& Ellar, 1982).

Clostridium perfringens type A enterotoxin (CPE) is a $34 \mathrm{kDa}$ protein which is responsible for the clinical symptoms associated with food poisoning caused by this organism (Labbe, 1989; $\mathrm{McDonel}, 1980$ ). CPE is synthesized intracellularly during sporulation of $C$. perfringens and released upon sporangial autolysis (Labbe, 1980). However, not all strains of $C$. perfringens type A produce CPE in significant amounts during sporulation (Skjelkvale \& Duncan, 1975). This has led to the designation of enterotoxin-positive $\left(\right.$ Ent $\left.^{+}\right)$and enterotoxin-negative (Ent $\left.{ }^{-}\right)$strains of this organism. The function of CPE in the sporulation process of this organism is unknown. It has been described as a sporulation-specific gene product (Duncan et al., 1972) and a structural component of the spore coat (Frieben \& Duncan, 1973, 1975). Several lines of evidence, including relative kinetics of sporulation and CPE formation (Labbe \& Duncan 1977b), genetic studies (Duncan et al., 1972), structural relationship between spore coat protein and CPE, and stability of mRNA coding for coat protein and CPE (Labbe \& Duncan, 1977a), indicate that enterotoxin of $C$. perfringens type $A$ is possibly excess or misregulated spore coat protein which is

\footnotetext{
Abbreviations: CPE, Clostridium perfringens enterotoxin; DTT, dithiothreitol ; Ent ${ }^{+}$, enterotoxin-positive; Ent ${ }^{-}$, enterotoxin-negative; IAA, iodoacetamide; PMSF, phenylmethylsulphonyl fluoride.
} 
not incorporated as a structural component of the spore coat (Labbe, 1980). Why some strains of $C$. perfringens fail to synthesize significant amounts of CPE during sporulation is unknown. Further confusion results from studies showing that a small amount of CPE can also be detected in vegetative cells of $C$. perfringens (Goldner et al., 1986; Granum et al., 1984), suggesting that CPE protein is not associated with spore components (Nillo, 1977; Walker, 1985).

The difficulties in solubilizing and preventing subsequent aggregation of spore coat protein have made quantitative chemical and physical analyses of this protein difficult. A more complete analysis of spore coat protein is essential to understand the relationship between spore coat protein and CPE. To this end we determined in this study the immunological relationship between $\mathrm{CPE}$ and coat proteins from two $\mathrm{Ent}^{+}$and two $\mathrm{Ent}^{-}$strains of $C$. perfringens type A using anti-CPE antibody.

\section{METHODS}

Bacterial strains. Spores of four strains of $C$. perfringens type A were used. These included two enterotoxinpositive strains (NCTC 8239, NCTC 8798) and two enterotoxin-negative strains (ATCC 3624, FD1). All strains were maintained frozen in cooked meat medium (Difco).

Growth and sporulation conditions. Stock cultures from each strain were inoculated into Fluid Thioglycollate Medium (FTG, BBL Microbiology Systems) and heat-activated at $75^{\circ} \mathrm{C}$ for $10 \mathrm{~min}$ followed by incubation at $37^{\circ} \mathrm{C}$ for $16-18 \mathrm{~h}$. These cultures were inoculated $(1 \%, \mathrm{v} / \mathrm{v}$, inoculum) into DS sporulation medium (Duncan \& Strong, 1968) and incubated for $8 \mathrm{~h}$ at $37^{\circ} \mathrm{C}$. The frequency of sporulation was $70-80 \%$.

Preparation of spores. Sporulating cultures were harvested by centrifugation at $10000 \mathrm{~g}$ for $20 \mathrm{~min}$. Cells were disrupted by ultrasonication in an ice-water bath in the presence of $1 \mathrm{mM}$-phenylmethylsulphonyl fluoride (PMSF) and $3 \mathrm{mM}$-EDTA to prevent proteolytic degradation (Loffler \& Labbe, 1983). The spores were washed extensively three times each with $2 \mathrm{M}-\mathrm{NaCl}$ and $0.14 \mathrm{M}-\mathrm{NaCl}$, and five times with deionized water. The effectiveness of the wash procedure in removing non-specifically adsorbed CPE from the spores was confirmed in separate experiments by the removal of toxin by this method from cleaned spores which had been mixed with purified CPE. The clean spores were lyophilized and stored at $-20^{\circ} \mathrm{C}$.

Preparation of spore coats. Spore coats were isolated by the method of Frieben \& Duncan (1973). Clean spores were suspended $\left(25 \mathrm{mg} \mathrm{ml}^{-1}\right)$ in distilled water and broken by shaking in a Mickle homogenizer with an amount of glass beads twice that of the spore suspension (w/v) plus one drop of antifoam for about $40 \mathrm{~min}$ at $4{ }^{\circ} \mathrm{C}(3 \mathrm{~min}$ of cooling after every 3-4 min of shaking). Suspensions were examined by phase-contrast microscopy to monitor breakage. The supernatant was decanted after breakage, and the glass beads were washed twice with distilled water. The supernatants were pooled and centrifuged at $200000 \mathrm{~g}$ for $1.5 \mathrm{~h}$ at $4{ }^{\circ} \mathrm{C}$ using a Beckman model L8-70M centrifuge with a $75 \mathrm{Ti}$ rotor. The supernatants were saved for analysis by Western blotting and the pellets suspended in $0.1 \mathrm{M}$-Tris/ $\mathrm{HCl}$ buffer $\mathrm{pH} 8.0$ and treated with $100 \mu \mathrm{g}$ lysozyme $\mathrm{ml}^{-1}$ for $2 \mathrm{~h}$ at $37^{\circ} \mathrm{C}$ to remove cortex peptidoglycan. The resulting coats were washed three times each with $1 \mathrm{M}-\mathrm{NaCl}, 0.02 \mathrm{M}$-sodium phosphate buffer $\mathrm{pH} 7 \cdot 0,0 \cdot 15 \mathrm{M}-\mathrm{NaCl}$, and distilled water, then lyophilized and stored at $-20^{\circ} \mathrm{C}$.

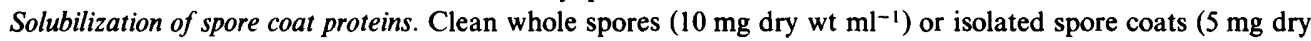
wt $\mathrm{ml}^{-1}$ ) were suspended in a freshly prepared $50 \mathrm{mM}$-glycine/ $\mathrm{NaOH}$ buffer $\mathrm{pH} 9.7$ containing $(a) 1 \%$ (w/v) SDS or (b) $50 \mathrm{~mm}$-dithiothreitol (DTT) plus $1 \%$ (w/v) SDS. The suspensions were incubated at $37^{\circ} \mathrm{C}$ for $2 \mathrm{~h}$ with gentle stirring (Franceschini \& Labbe, 1979). After centrifugation at $12000 \mathrm{~g}$ for $10 \mathrm{~min}$, the supernatant, containing the solubilized coat protein, was collected. Depending on the strains, method (a) solubilized 3-7\% of total spore weight while method $(b)$ solubilized $18-37 \%$ of total spore weight (Table $1 a, b$ ).

Protein assay. Protein concentration was assayed by the method of Bradford (1976), using bovine serum albumin as a standard.

Alkylation of solubilized spore coat protein. The solubilized spore coat proteins $\left(0.5 \mathrm{ml}\right.$ of $1.5 \mathrm{mg}$ protein ml $\left.{ }^{-1}\right)$ were alkylated by incubation with $110 \mathrm{~mm}$-iodoacetamide (IAA) for $20 \mathrm{~min}$ at room temperature in the dark (Lane, 1977).

SDS-PAGE. This was done by the method of Hames (1983) using a 5-18\% acrylamide gradient slab gel $(2.6 \%$ bisacrylamide) containing $0.1 \%$ SDS. A stacking gel was not used because the solubilized spore coat proteins formed aggregates at low $\mathrm{pH}$. The solubilized spore coat protein samples $\left(1.5 \mathrm{mg}\right.$ protein $\mathrm{ml}^{-1}$ or, in the case of gold staining procedures, $0.1 \mathrm{mg}$ protein $\left.\mathrm{ml}^{-1}\right)$ were mixed directly with the final concentrations of $10 \%(\mathrm{w} / \mathrm{v})$ sucrose and $0.002 \%(\mathrm{w} / \mathrm{v})$ bromophenol blue; $10 \mu \mathrm{l}$ of these mixtures was applied to each sample well. Electrophoresis was done at $25 \mathrm{~mA}$ constant current for about $4 \mathrm{~h}$. The gels were either stained with $0 \cdot 1 \%(\mathrm{w} / \mathrm{v})$ Coomassie blue G250 in water/methanol/glacial acetic acid $(5: 5: 2$, by vol.) or analysed by Western blotting. Bovine serum albumin $(66 \mathrm{kDa})$, ovalbumin $(45 \mathrm{kDa})$, carbonic anhydrase $(29 \mathrm{kDa})$, myoglobin $(18.8 \mathrm{kDa})$ and lysozyme $(14.3 \mathrm{kDa})$ were used as molecular mass markers.

Preparation of antiserum against CPE. CPE was purified generally according to the method of Granum \& Whitaker (1980). The $0-15 \%$ ammonium sulphate precipitate from a cell extract of an $8 \mathrm{~h}$ sporulating culture of $C$. 
perfringens type A strain NCTC 8239 was dissolved in $0.02 \mathrm{M}$-sodium phosphate buffer pH 6.8 and chromatographed on a Sephacryl S-200 HR (Pharmacia) column $(2.5 \times 70 \mathrm{~cm})$ in the same buffer at $4{ }^{\circ} \mathrm{C}$. The fractions with the highest protein concentration associated with the CPE peak were pooled and used for antiserum production. The CPE was electrophoretically pure on Coomassie-blue-stained acrylamide gels (5-18\% gradient). The purified CPE was mixed with an equal volume of Maalox (William H. Rorer, Inc., Fort Washington, Pennsylvania, USA) prior to injection into New Zealand White rabbits. Five weekly intramuscular injections of $100 \mu \mathrm{g} \mathrm{CPE}$ were followed by an intravenous dose of $200 \mu \mathrm{g}$ CPE during the sixth week. Serum was collected $10 \mathrm{~d}$ later by bleeding from the marginal ear vein. Pre-immune serum was collected before the first injection of CPE and gave no reaction in immunoassays.

Preparation of antiserum against $34 \mathrm{kDa}$ spore coat protein. The $34 \mathrm{kDa}$ spore coat protein was purified by electrophoretic fractionation in preparative SDS-PAGE. The protein bands were visualized by immersing the gel in $7 \%(\mathrm{v} / \mathrm{v})$ acetic acid $/ 10 \%(\mathrm{v} / \mathrm{v})$ ethanol solution for $15 \mathrm{~min}$. The $34 \mathrm{kDa}$ coat protein band was excised, rinsed with distilled water, homogenized with Maalox and used to prepare antiserum as described above.

Purification of $34 \mathrm{kDa}$ coat protein antibody by affinity chromatography. CPE was coupled to CNBr-activated Sepharose 4B as recommended by the manufacturer (Pharmacia) at a concentration of $2 \mathrm{mg}$ CPE per ml of swollen Sepharose gel. Antibody to CPE was removed by passing the $34 \mathrm{kDa}$ coat protein antiserum through the CPEbound Sepharose $4 \mathrm{~B}$ in the presence of $0.05 \%$ Tween 20 at a flow rate of $0.3 \mathrm{ml} \mathrm{min}-1$.

Enzyme-linked immunosorbent assay (ELISA) of spore coat protein. The amount of CPE-related proteins in the spore coat of $\mathrm{Ent}^{+}$and $\mathrm{Ent}^{-}$strains of $C$. perfringens was estimated by the indirect ELISA procedure of McClane \& Strouse (1984) with some modifications. Samples of CPE and solubilized spore coat proteins in $100 \mu l$ coating buffer ( $50 \mathrm{~mm}$-sodium carbonate/bicarbonate buffer $\mathrm{pH} 9.6$ ) were added to wells of a microtitre plate, and incubated in a humidity chamber at $37^{\circ} \mathrm{C}$ for $3 \mathrm{~h}$. The plate was washed five times with phosphate-buffered saline/Tween 20 (PBS-Tween 20: NaCl, 8.0 g; $\mathrm{KH}_{2} \mathrm{PO}_{4}, 0.2 \mathrm{~g} ; \mathrm{Na}_{2} \mathrm{HPO}_{4} .12 \mathrm{H}_{2} \mathrm{O}, 2.9 \mathrm{~g} ; \mathrm{KCl}, 0.2 \mathrm{~g} ; \mathrm{NaN}_{3}, 0.2 \mathrm{~g}$; Tween 20,0.5 ml, in 1 litre of distilled $\mathrm{H}_{2} \mathrm{O}, \mathrm{pH} 7 \cdot 4$ ), then $100 \mu \mathrm{l} \mathrm{CPE}$ antiserum diluted $1: 500$ with PBS-Tween 20 was added to each well and allowed to bind to the adsorbed antigen for $1.5 \mathrm{~h}$ at $37^{\circ} \mathrm{C}$. The plates were then washed five times with PBS-Tween 20, and $100 \mu$ l goat anti-rabbit IgG-alkaline phosphatase conjugate (Sigma) diluted $1: 1000$ with conjugate buffer [PBS-Tween 20 containing $2 \%(\mathrm{w} / \mathrm{v})$ polyvinylpyrrolidone $\left(M_{r} 10000\right)$ and $0 \cdot 2 \%$ BSA] was added to each well. After incubation at $37^{\circ} \mathrm{C}$ for $1.5 \mathrm{~h}$, the wells were washed five times with PBSTween 20 . Then $200 \mu$ l enzyme substrate $(0 \cdot 1 \% p$-nitrophenol phosphate in $10 \%, \mathrm{v} / \mathrm{v}$, diethanolamine, pH 9.8$)$ was added to each well. Release of $p$-nitrophenol was measured spectrophotometrically at $405 \mathrm{~nm}$ in an ELISA reader (Dynatec). Each experiment was done in triplicate with two wells per sample.

Western blotting. Proteins separated by SDS-PAGE were transferred electrophoretically onto a $0 \cdot 22 \mu \mathrm{m}$ Nitroplus 2000 membrane (Micron Separations) at $100 \mathrm{~V}$ for about $3.5 \mathrm{~h}$ using a buffer composed of $12.5 \mathrm{mM}$-Tris plus $81 \mathrm{~mm}$-glycine as recommended by the manufacturer (Bio-Rad). The transfer unit was kept cold by immersion in an ice-water bath.

(a) Immunoassay. The blotted membranes were incubated for $40-50 \mathrm{~min}$ in BLoTro $[5 \%(\mathrm{w} / \mathrm{v})$ nonfat dry milk in Tris-buffered saline (TBS: $20 \mathrm{~mm}$-Tris, $500 \mathrm{~mm}-\mathrm{NaCl}, \mathrm{pH} 7 \cdot 5$ )] (Johnson et al., 1984) to block the remaining binding sites. After washing with TTBS $(0.05 \%$ Tween 20 in TBS), these membranes were incubated overnight with rabbit anti-CPE IgG, washed twice with TTBS, then incubated with horseradish-peroxidase-conjugated goat anti-rabbit IgG $(\mathrm{H}+\mathrm{L})$ (Bio-Rad) for $\mathrm{l} \mathrm{h}$. The unbound conjugate was removed by washing twice with TTBS and once with TBS. The peroxidase was developed with 0.06\% 4-chloro-1-naphthol and $0.006 \%$ hydrogen peroxide in TBS for 15-30 min. All procedures were carried out at room temperature with gentle agitation. The molecular mass estimation of CPE-related protein bands was done by comparing a duplicate protein blot in which total coat protein and molecular mass standards were stained with colloidal gold solution.

(b) Gold staining. This was done as recommended by the manufacturer (Bio-Rad). The blotted membranes were washed three times each for 20 min with $0.3 \%$ Tween 20 in TBS. After rinsing with type I grade water (Milli-Q system, Millipore) the membranes were soaked in a colloidal gold solution for about $1.5 \mathrm{~h}$ and rinsed with type I grade water.

(c) Affinity purification of antibody to the $48 \mathrm{kDa}$ coat protein. SDS-polyacrylamide slab gels without combs were used for separation of coat proteins as described above. Following electrophoretic transfer the entire Nitroplus membrane was treated with CPE antiserum, also as described above. A small portion of the membrane was further treated with the conjugated enzyme probe to identify the location of the $48 \mathrm{kDa}$ protein, which was then cut from the remaining membrane. This strip was washed three times with TTBS and the antibody separated and eluted by immersion for $20 \mathrm{~min}$ with gentle agitation in $0.1 \mathrm{M}$-glycine buffer $\mathrm{pH} 2.3$ at $4{ }^{\circ} \mathrm{C}$.

Electron microscopy. Freshly prepared spores were suspended in $1 \%(\mathrm{v} / \mathrm{v})$ glutaraldehyde (in $0.2 \mathrm{M}$-sodium cacodylate $\mathrm{pH} 7.4$ ) for $2 \mathrm{~h}$, washed in $0.05 \mathrm{M}$-sodium cacodylate $\mathrm{pH} 7 \cdot 4$, and postfixed in $1 \%(\mathrm{w} / \mathrm{v}) \mathrm{osmium}$ tetroxide (in $0.2 \mathrm{M}$-sodium cacodylate $\mathrm{pH} \mathrm{7.4)} \mathrm{for} 2 \mathrm{~h}$. After washing with $0.05 \mathrm{M}$-sodium cacodylate, centrifuged pellets were enrobed in $1 \mathrm{ml} \mathrm{2 \%}$ Noble agar (Difco), dehydrated in ethanol, and embedded in Epon 812 . The sections were stained for $15 \mathrm{~min}$ with $5 \%(\mathrm{w} / \mathrm{v})$ uranyl acetate followed by $0.4 \%(\mathrm{w} / \mathrm{v})$ lead acetate for $15 \mathrm{~min}$ and were examined using a Zeiss EM9S-2 electron microscope at an accelerating voltage of $60 \mathrm{kV}$ (Labbe \& Rufner, 1980). 


\section{RESULTS}

$S D S-P A G E$ of solubilized spore coat protein. Spore coat proteins solubilized with DTT and SDS at $\mathrm{pH} 9.7$ were resolved by 5-18\% acrylamide gradient SDS-PAGE. However, these proteins showed relatively broad bands because of the re-oxidation of thiol-containing proteins of spore coats during SDS-PAGE (Fig. $1 b$ ). Sharp bands resulted when the alkylating agent IAA was used to stabilize the free thiol groups of coat protein through carboxyamidomethylation (Fig. 1a). Similar results were obtained when the concentration of IAA was increased to $200 \mathrm{mM}$ (not shown).

The solubilized coat proteins from the four strains of $C$. perfringens showed multiple protein bands, in agreement with results obtained by others (Frieben \& Duncan, 1975; Labbe \& Duncan, $1977 b$; Tsuzuki \& Ando, 1985). The coat protein patterns of the two Ent ${ }^{+}$strains were similar, and were distinct from those of the two Ent $^{-}$strains, which again were very similar (Fig. 1a). The two major group-specific coat proteins for $\mathrm{Ent}^{+}$strains had molecular masses of 19 and $34 \mathrm{kDa}$. A third band $(25 \mathrm{kDa})$ was sometimes present, but it varied in intensity among experiments and is not considered a major protein of Ent ${ }^{+}$strains. The Ent ${ }^{-}$ strains showed major protein bands at $19 \mathrm{kDa}$ and $28 \mathrm{kDa}$ (Fig. $1 a$ ). Thus the $19 \mathrm{kDa}$ protein was common to all four strains.

Immunoblot analysis of spore coat protein and CPE. Solubilized and alkylated spore coat proteins and CPE were analysed by Western blotting using CPE antiserum. CPE aggregated in the presence of SDS (Fig. 2b), confirming previous observations (Enders \& Duncan, 1976; Salinovich et al., 1982). Aggregation of CPE in the presence of SDS is an inherent characteristic of this protein. However, no aggregation occurred if the CPE concentration was below $15 \mu \mathrm{g}$ $\mathrm{ml}^{-1}$. The serological activity of CPE is not affected by treatment with IAA (Granum \& Skjelkvale, 1977).

Two CPE-related protein bands with molecular masses of 34 and $48 \mathrm{kDa}$ were found in the spore coat proteins of the Ent ${ }^{+}$strains, while only the $48 \mathrm{kDa}$ CPE-related protein was found in the spore coat fraction of the Ent ${ }^{-}$strains (Fig. $2 a$ ). The amount of these CPErelated proteins in the spore coat of $C$. perfringens was relatively small because the $48 \mathrm{kDa}$ band was not a major coat protein band and the $34 \mathrm{kDa}$ band showed very weak reactivity to antiCPE antibody following Western blotting considering the amount of protein in that band. This suggests that the $34 \mathrm{kDa}$ protein possesses the same molecular mass as, but is only partially related to, CPE, or that this band consists of a small amount of CPE and a coat protein which has the same molecular mass as CPE.

Antibody prepared against the isolated $34 \mathrm{kDa}$ spore coat protein band cross-reacted with $\mathrm{CPE}$ as well as the $34 \mathrm{kDa}$ coat protein. After removal of the anti-CPE immunoglobulin fraction by affinity chromatography (using CPE-coupled CNBr-activated Sepharose 4B) the specificity of the antiserum was limited to the $34 \mathrm{kDa}$ spore coat protein. This indicates that the $34 \mathrm{kDa}$ coat protein band is composed of a small amount of CPE as well as a spore coat protein of similar molecular mass. This affinity-purified antibody to the $34 \mathrm{kDa}$ coat protein did not react with the $48 \mathrm{kDa}$ coat protein, which suggests that synthesis of $34 \mathrm{kDa}$ coat protein is not related to that of the $48 \mathrm{kDa}$ coat protein.

Specificity of anti-CPE serum. Affinity-purified antibody to the $48 \mathrm{kDa}$ protein reacted with $\mathrm{CPE}$ in immunoblots (not shown), confirming that the $48 \mathrm{kDa}$ protein was immunologically related to the $34 \mathrm{kDa} \mathrm{CPE}$-related protein.

Concentration of CPE-related proteins in the spore coat. The spore coats of the Ent ${ }^{+}$strains contained about threefold more CPE-related proteins than those of the Ent ${ }^{-}$strains (Table $1 a$ ). The extracted coats of Ent ${ }^{+}$and Ent ${ }^{-}$strains were composed of $2.7 \%$ and $0.8 \% \mathrm{CPE}-$ related protein, respectively. These relatively small values confirm the qualitative results obtained by immunoblot analysis (above).

Solubilization of spore coat proteins by SDS. One percent SDS alone could solubilize only part of the spore coat (Fig. 3; and compare Table $1 a$ with Table $1 b$ ), but it solubilized most of the CPE- 

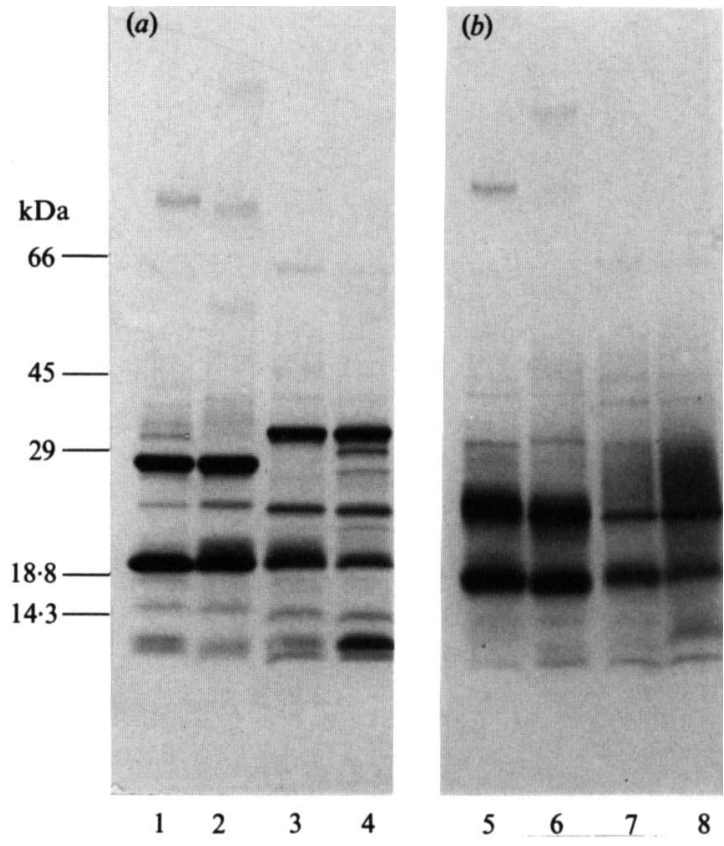

Fig. 1. SDS-PAGE (5-18\% gradient) of spore coat proteins from two $\mathrm{Ent}^{+}$(NCTC 8239, NCTC 8798), and two Ent ${ }^{-}$(FD1, ATCC 3624) strains of C. perfringens type A. Spore coat proteins were extracted from intact spores with $50 \mathrm{~mm}$-glycine/ $\mathrm{NaOH}$ buffer containing $50 \mathrm{~mm}$-DTT $+1 \%$ SDS and $(a)$ alkylated with $110 \mathrm{~mm}$-IAA or $(b)$ non-alkylated. Gels were stained withh Coomassie blue G250. Lanes: 1 and 5, ATCC 3624; 2 and 6, FD1; 3 and 7, NCTC 8798; 4 and 8, NCTC 8239. Locations of molecular mass standards are shown on the left.
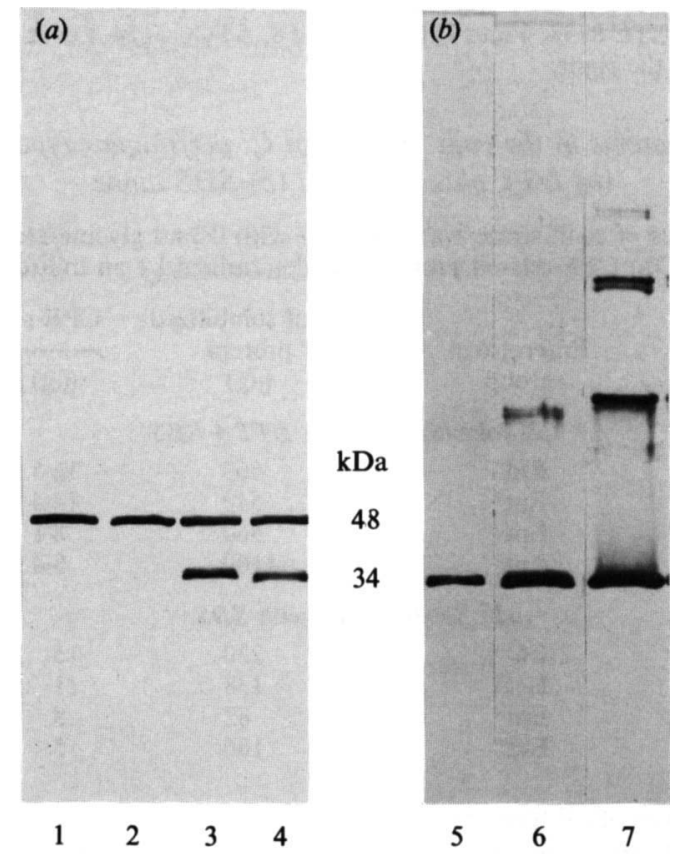

Fig. 2. Immunoblot analysis, using CPE antiserum, of CPE and spore coat proteins from Ent ${ }^{+}$ (NCTC 8239, NCTC 8798) and Ent $^{-}$(FD1, ATCC 3624) strains of $C$. perfringens. Coat proteins were treated with IAA as described in the legend to Fig. 1. (a) Spore coat proteins. Lanes: 1, ATCC 3624; 2 , FD1; 3, NCTC 8798; 4, NCTC 8239. (b) CPE (from NCTC 8239). Lanes: 5, 150 ng; 6, 800 ng; 7, $2200 \mathrm{ng}$. 

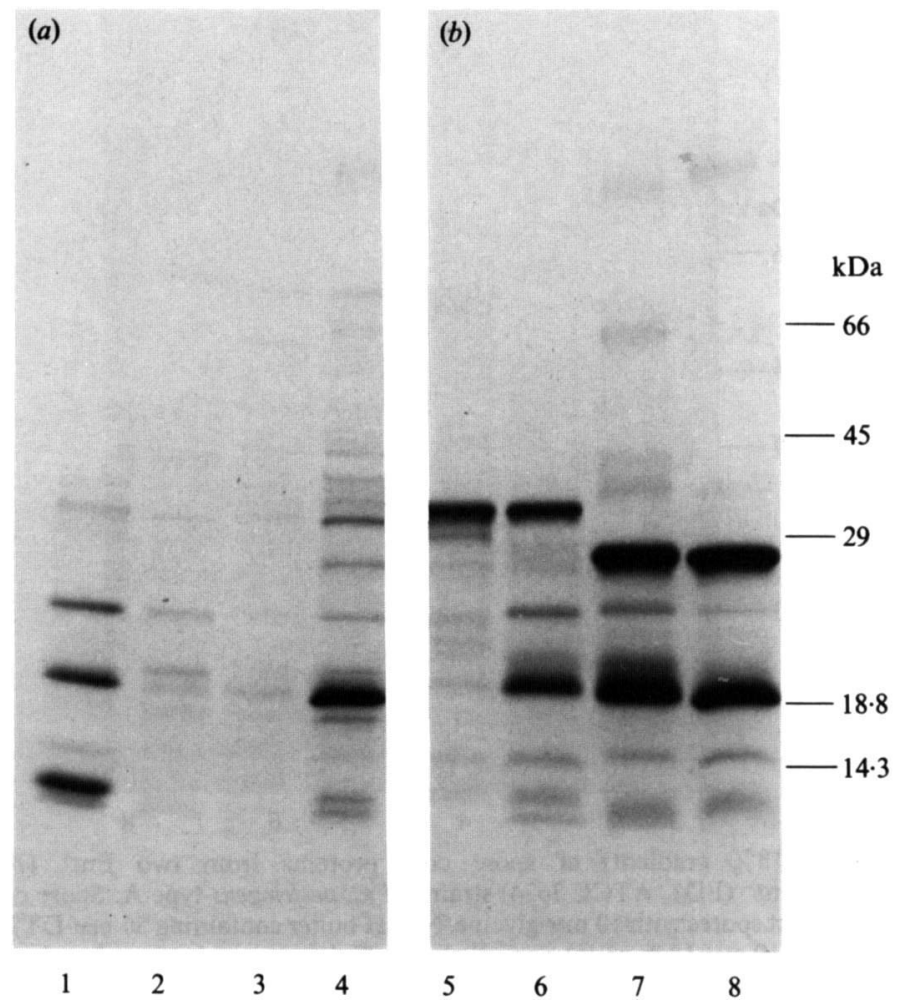

Fig. 3. SDS-PAGE (5-18\% gradient) of spore coat proteins from Ent ${ }^{+}$(NCTC 8239, NCTC 8798) and Ent $^{-}$(FD1, ATCC 3624) strains of $C$. perfringens extracted with $1 \%$ SDS only $(a)$ and subsequently with $1 \%$ SDS plus $50 \mathrm{~mm}$-DTT $(b)$. Gels were stained with Coomassie blue G250. Lanes: 1 and 5 , NCTC 8239; 2 and 6, NCTC 8798; 3 and 7, FDl; 4 and 8, ATCC 3624. Locations of molecular mass standards are shown on the right.

Table 1. CPE-related proteins in the coat proteins of $C$. perfringens type A spores solubilized by (a) DTT plus SDS and (b) SDS alone

A $3 \mathrm{mg}$ sample of spores of each strain was extracted with $0 \cdot 3 \mathrm{ml}$ glycine/ $\mathrm{NaOH}$ buffer containing $50 \mathrm{mM}-\mathrm{DTT}$ plus $1 \%$ SDS; CPE-related protein was determined by an indirect ELISA.

\begin{tabular}{|c|c|c|c|c|}
\hline \multirow[b]{2}{*}{ Strain } & \multirow{2}{*}{$\begin{array}{l}\text { Enterotoxin } \\
\text { group }\end{array}$} & \multirow{2}{*}{$\begin{array}{c}\text { Total solubilized } \\
\text { protein } \\
(\mu \mathrm{g})\end{array}$} & \multicolumn{2}{|c|}{ CPE-related protein } \\
\hline & & & $(\mu \mathrm{g})$ & $(\%)$ \\
\hline \multicolumn{5}{|c|}{ (a) Solubilization with $D T T+S D S$} \\
\hline NCTC 8239 & Ent $^{+}$ & 660 & $16 \cdot 5$ & $2 \cdot 5$ \\
\hline NCTC 8798 & $\mathrm{Ent}^{+}$ & 540 & $14 \cdot 4$ & $2 \cdot 7$ \\
\hline FDl & Ent $^{-}$ & 960 & $8 \cdot 1$ & 0.84 \\
\hline ATCC 3624 & Ent $^{-}$ & 1100 & 8.4 & 0.76 \\
\hline \multicolumn{5}{|c|}{ (b) Solubilization with SDS } \\
\hline NCTC 8239 & Ent $^{+}$ & 220 & 15 & 6.8 \\
\hline NCTC 8798 & $\mathrm{Ent}^{+}$ & 138 & 11 & $8 \cdot 0$ \\
\hline FD1 & Ent $^{-}$ & 82 & 8 & $9 \cdot 8$ \\
\hline ATCC 3624 & Ent $^{-}$ & 165 & 5 & $3 \cdot 0$ \\
\hline
\end{tabular}

related proteins from spores of all four strains. The relative effectiveness of SDS versus SDS plus DTT was confirmed by electron micrographs of extracted spores of strain NCTC 8239 (Fig. 4). These show that the SDS plus DTT treatment removed all of the spore coat but that SDS treatment alone removed only part of it. Although most of CPE-related protein was extractable using SDS alone (Table $1 a$ vs Table $1 b$ ), this amount was not related to the Ent phenotype. 


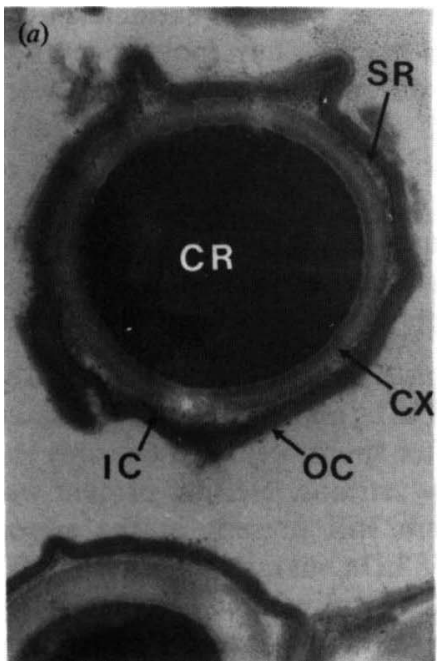

\section{(b)}

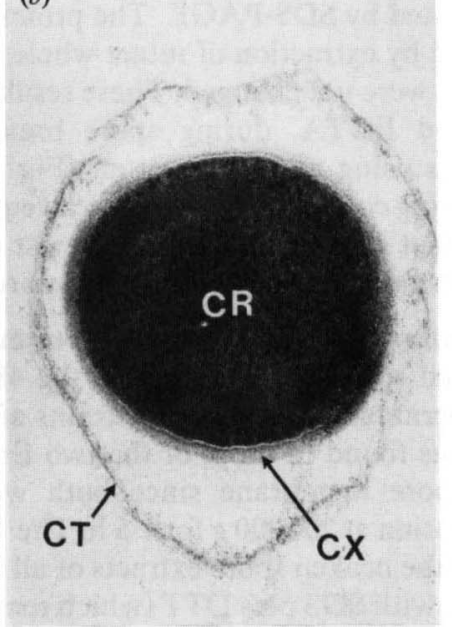

(c)

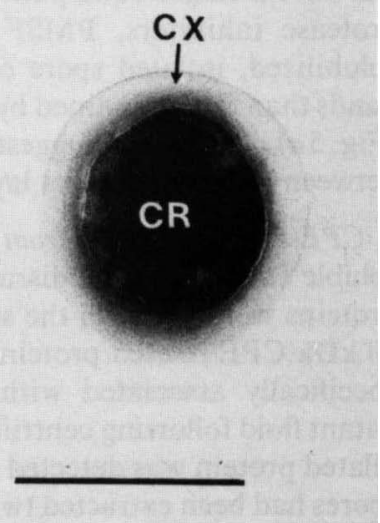

Fig. 4. Electron micrographs of thin sections of $C$. perfringens NCTC $8239\left(\right.$ Ent $\left.^{+}\right)$spores. $(a)$ Intact spore, $(b)$ spore extracted with $1 \%$ SDS, (c) spore extracted with $1 \%$ SDS plus 50 mM-DTT. CT, coat; IC, inner coat; OC, outer coat; CX, cortex; CR, core; SR, subcoat region. Bar 0.5 $\mu \mathrm{m}$.
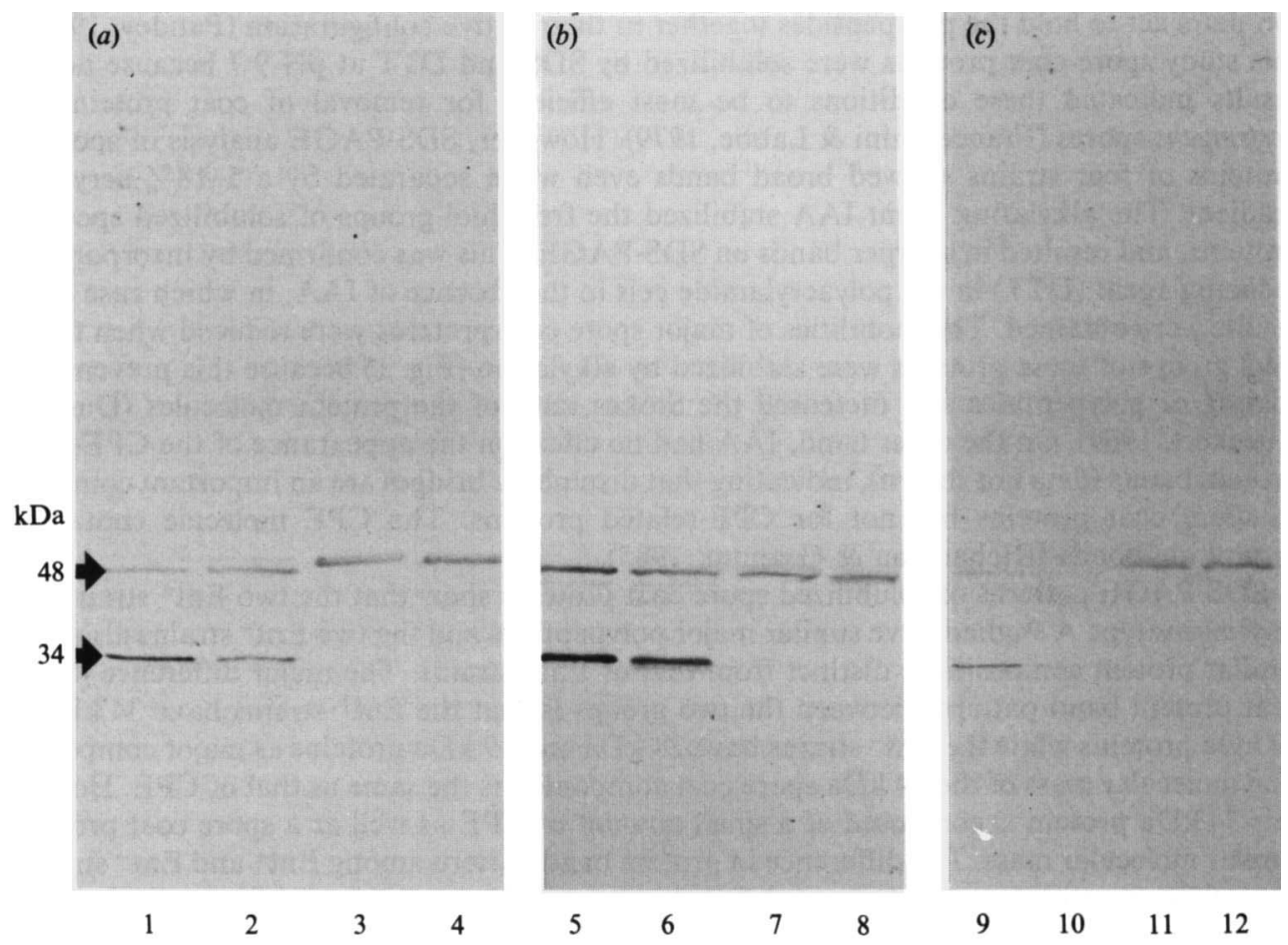

Fig. 5. Immunoblot analysis, using CPE antiserum, of spore coat proteins of Ent ${ }^{+}$(NCTC 8239, NCTC 8798) and Ent $^{-}$(FD1, ATCC 3624) strains of $C$. perfringens from $(a)$ intact whole spores, $(b)$ supernatant from whole spores disrupted in distilled water, and $(c)$ isolated spore coats. Isolated spore coats were prepared as described in Methods; $30 \mu \mathrm{g}$ of each protein was added to each lane. Lanes: 1, 5 and 9, NCTC 8239; 2, 6 and 10, NCTC 8798; 3, 7 and 11 , FD1; 4, 8 and 12, ATCC 3624. 
Coat and CPE-related proteins from isolated spore coats. Spore coat proteins extracted from isolated spore coats were separated by SDS-PAGE. The protein band pattern (not shown) was very similar to the one obtained by extraction of intact whole spores. Some minor bands were lost but the major band patterns were not changed. These results were not affected by the use of protease inhibitors, PMSF and EDTA, during spore breakage. Immunoblot analysis of solubilized, isolated spore coats using anti-CPE serum (Fig. $5 c$ ) yielded similar but weaker bands than those obtained by using coats solubilized from an equivalent amount of whole spores (Fig. 5a). This result suggests that CPE-related proteins exist in the spore core or are trapped between the core and coat layers and released during spore disruption (to obtain isolated coats).

$C P E$-related proteins from broken spores. CPE-related proteins were readily detected in the soluble fraction of the disrupted spores (Fig. $5 b$ ). Both the $48 \mathrm{kDa}$ and $34 \mathrm{kDa}$ CPE-related proteins were found in the supernatants of two $\mathrm{Ent}^{+}$strains after spore breakage but only the $48 \mathrm{kDa}$ CPE-related protein was found in those of the two Ent ${ }^{-}$strains. Neither protein was specifically associated with spore membrane since both were still present in the supernatant fluid following centrifugation at $200000 \mathrm{~g}$ for $1.5 \mathrm{~h}$. The $48 \mathrm{kDa}$ but not the $34 \mathrm{kDa}$ CPErelated protein was detected in the broken spore extracts of all four strains even after the intact spores had been extracted twice with SDS plus DTT (which removed spore coats). This suggests that the $34 \mathrm{kDa}$ protein is located external to the cortex but that the $48 \mathrm{kDa}$ protein is not limited to such a location.

\section{DISCUSSION}

The difficulties in solubilizing and handling spore coat proteins are well known. The complex morphology and tendency of solubilized coat proteins to aggregate show that forces such as covalent bonding, inter-, and intra-molecular hydrophobic interactions, disulphide bridges and ion pairs act to hold the polypeptides together in their native configuration (Pandey, 1980). In this study spore coat proteins were solubilized by SDS and DTT at $\mathrm{pH} 9.7$ because previous results indicated these conditions to be most efficient for removal of coat protein of $C$. perfringens spores (Franceschini \& Labbe, 1979). However, SDS-PAGE analysis of spore coat proteins of four strains showed broad bands even when separated by a $5-18 \%$ acrylamide gradient. The alkylating agent IAA stabilized the free thiol groups of solubilized spore coat proteins, and resulted in sharper bands on SDS-PAGE. This was confirmed by incorporating a reducing agent (DTT) in the polyacrylamide gels in the absence of IAA, in which case similar results were obtained. The mobilities of major spore coat proteins were reduced when the free thiol groups of these proteins were stabilized by alkylation (Fig. 1) because this prevented the folding of polypeptides and increased the Stokes radii of the protein molecules (Dunker \& Rueckert, 1969). On the other hand, IAA had no effect on the appearance of the CPE-related protein bands (data not shown), indicating that disulphide bridges are an important component in spore coat proteins but not for CPE-related proteins. The CPE molecule contains no disulphide bonds (Richardson \& Granum, 1985).

SDS-PAGE patterns of solubilized spore coat proteins show that the two Ent ${ }^{+}$strains of $C$. perfringens type A studied have similar major polypeptides and the two Ent ${ }^{-}$strains also have a similar protein composition, distinct from that of $\mathrm{Ent}^{+}$strains. The major difference in spore coat protein band patterns between the two groups is that the $\mathrm{Ent}^{+}$strains have $34 \mathrm{kDa}$ and $19 \mathrm{kDa}$ proteins while the $\mathrm{Ent}^{-}$strains have $28 \mathrm{kDa}$ and $19 \mathrm{kDa}$ proteins as major components. The molecular mass of the $34 \mathrm{kDa}$ spore coat component is the same as that of CPE. However, this $34 \mathrm{kDa}$ protein is composed of a small amount of CPE as well as a spore coat protein of similar molecular mass. The difference in protein band pattern among Ent ${ }^{+}$and $\mathrm{Ent}^{-}$strains of $^{-}$ C. perfringens seems to suggest some relationship between spore coat protein formation and CPE production mechanisms.

There have been conflicting reports regarding the presence of CPE-related proteins in the spore coat (Frieben \& Duncan, 1975; Labbe \& Duncan, 1977b). Using immunodiffusion methods Frieben \& Duncan (1975) reported the presence of a $36.5 \mathrm{kDa}$ CPE-related protein in coats of two Ent ${ }^{+}$strains (NCTC 8798 and NCTC 8239) and a $14.5 \mathrm{kDa}$ protein in one Ent ${ }^{-}$ 
strain (FD1). However, using the same strains plus an additional Ent ${ }^{-}$strain (ATCC 3624) we found 34 and $48 \mathrm{kDa}$ CPE-related proteins in both Ent ${ }^{+}$strains but only the $48 \mathrm{kDa}$ CPE-related protein in both Ent ${ }^{-}$strains. Frieben \& Duncan's procedure differs in that they did not treat their extracted coat proteins with IAA nor include SDS during PAGE.

CPE reportedly aggregates in the presence of SDS (Enders \& Duncan, 1976). The aggregation pattern of purified CPE on immunoblots (Fig. $2 b$ ) did not show a $48 \mathrm{kDa}$ band. Furthermore, Ent $^{-}$strains showed the $48 \mathrm{kDa}$ band in the absence of $34 \mathrm{kDa}$ band. These results indicate that the $48 \mathrm{kDa}$ CPE-related protein was not a result of aggregation by SDS. We could not identify CPE-related proteins by non-denaturing PAGE because of smearing of the protein bands. Our failure to detect a $14.5 \mathrm{kDa}$ CPE-related protein in the spores of strain FD1 as reported by Frieben \& Duncan (1975) may be due to a variation in the specificity of antiserum. The CPE they used to raise antiserum was purified by a procedure different from ours.

The amount of CPE-related proteins in the spores of $C$. perfringens as measured by an indirect ELISA was relatively low. Regardless of the strain, CPE-related material composed less than $3 \%$ of total solubilized spore coat proteins. The CPE-related proteins could be solubilized by treatment with SDS alone or by simply breaking whole spores. Using a less sensitive immunodiffusion assay Frieben \& Duncan (1973) were unable to detect CPE-related proteins in broken spore extracts. These results suggest that CPE-related proteins are not major structural components of spore coat but exist in the spore core or are trapped between the core and coat layers.

The presence of a $48 \mathrm{kDa}$ CPE-related protein in spores of both $\mathrm{Ent}^{+}$and Ent ${ }^{-}$strains of $C$. perfringens suggests the presence of a possible precursor of CPE in strains of both groups. Perhaps only Ent ${ }^{+}$strains can process (probably by proteolysis) this protein to the $34 \mathrm{kDa} C P E$, leading to its accumulation in the sporulating cell. Up to three separate proteolytic enzymes are present in such cells (K. Park \& R. G. Labbe, unpublished results). However in such a scenario one would expect Ent ${ }^{-}$strains to contain a significantly greater amount of the $48 \mathrm{kDa}$ protein in their cell extracts. Since they do not, a different regulatory mechanism may be involved.

Further analysis of the synthesis and assembly of the individual coat proteins is needed to understand the relationship to CPE of the major and CPE-related proteins in the spore coats of C. perfringens.

This work was supported in part by the US Department of Agriculture Experiment Station project no. 578 .

\section{REFERENCES}

ARonson, A. I. \& Fitz-James, P. C. (1976). Structure and morphogenesis of the bacterial spore coat. Bacteriological Reviews 40, 360-402.

BRADFORD, M. M. (1976). A rapid and sensitive method for the quantitation of microgram quantities of protein utilizing the principle of protein-dye binding. Analytical Biochemistry 72, 248-254.

DunCAN, C. L. \& Strong, D. H. (1968). Improved medium for sporulation of Clostridium perfringens. Applied Microbiology 16, 82-84.

Duncan, C. L., Strong, D. H. \& Sebald, M. (1972). Sporulation and enterotoxin production by mutants of Clostridium perfringens. Journal of Bacteriology 110, 378-391.

Dunker, A. K. \& Rueckert, R. R. (1969). Observation on molecular weight determinations on polyacrylamide gel. Journal of Biological Chemistry 244, 5074-5080.

ENDERS, G. L., JR \& DunCaN, C. L. (1976). Anomalous aggregation of Clostridium perfringens enterotoxin under dissociating conditions. Canadian Journal of Microbiology 22, 1410-1414.
FranCESChINI, T. J. \& LABBE, R. G. (1979). Sensitivity of chemically treated spores of Clostridium perfringens type A to an initiation protein. Microbios 25, 8591.

Frieben, W. R. \& DunCaN, C. L. (1973). Homology between enterotoxin protein and spore structural protein in Clostridium perfringens type A. European Journal of Biochemistry 39, 393-401.

Frieben, W. R. \& DunCAN, C. L. (1975). Heterogeneity of enterotoxin-like protein extracted from spores of Clostridium perfringens type A. European Journal of Biochemistry 55, 455-463.

Goldman, R. C. \& TiPPER, D. J. (1978). Bacillus subtilis spore coats: complexity and purification of a unique polypeptide component. Journal of Bacteriology 135, 1091-1106.

Goldner, S. B., Solberg, M., Jones, S. \& Post, L. S. (1986). Enterotoxin synthesis by nonsporulating cultures of Clostridium perfringens. Applied and Environmental Microbiology 52, 407-412.

Granum, P. E. \& SkJelkvale, R. (1977). Chemical modification and characterization of enterotoxin 
from Clostridium perfringens type A. Acta Pathologica, Microbiologica et Immunologica Scandinavica Section B-Microbiology 85, 89-94.

Granum, P. E. \& Whitaker, J. R. (1980). Improved method for purification of enterotoxin from Clostridium perfringens type A. Applied and Environmental Microbiology 39, 1120-1122.

Granum, P. E., Telle, W., Olsvic, O. \& Stavn, A. (1984). Enterotoxin formation by Clostridium perfringens during sporulation and vegetative growth. International Journal of Food Microbiology 1, 43-49.

HaMes, B. D. (1983). Concentration gradient gels. In Gel Electrophoresis of Proteins, pp. 71-76. Edited by B. D. Hames \& D. Rickwood. Oxford: IRL Press.

JENKINSON, H. F. (1981). Germination and resistance defects in spores of a Bacillus subtilis mutant lacking a coat polypeptide. Journal of General Microbiology 127, 81-91.

JENKINSON, H. F. (1983). Altered arrangement of proteins in the spore coat of a germination mutant of Bacillus subtilis. Journal of General Microbiology 129, 1945-1958.

Jenkinson, H. F., SAwYeR, W. D. \& MANDElstaM, J. (1981). Synthesis and order of assembly of spore coat proteins in Bacillus subtilis. Journal of General Microbiology 123, 1-16.

Johnson, D. A., Gautsch, J. W., Sportsman, J. R. \& ELDER, J. H. (1984). Improved technique utilizing nonfat dry milk for analysis of proteins and nucleic acids transferred to nitrocellulose. Gene Analysis Techniques 1, 3-8.

KeYNAN, A. \& SANDleR, N. (1983). Spore research in historical perspective. In The Bacterial Spore 2, pp. 1-48. Edited by A. Hurst \& G. W. Gould. London: Academic Press.

Kutima, P. M. \& Foegeding, P. M. (19087). Involvement of the spore coat in germination of Bacillus cereus T spores. Applied and Environmental Microbiology 53, 47-52.

LABBE, R. G. (1980). Relationship between sporulation and enterotoxin production in Clostridium perfringens type A. Food Technology 34, 88-90.

LABBE, R. G. (1989). Clostridium perfringens. In Foodborne Bacterial Pathogens, pp. 191-234. Edited by M. Doyle. New York: Marcel Dekker.

LABBE, R. G. \& DUNCAN, C. L. (1977a). Evidence for stable messenger RNA during sporulation and enterotoxin synthesis by Clostridium perfringens type A. Journal of Bacteriology 129, 843-849.

LABbe, R. G. \& Duncan, C. L. (1977b). Spore coat protein and enterotoxin synthesis in Clostridium perfringens. Journal of Bacteriology 131, 713-715.

LABBE, R. G. \& RUFNER, R. (1980). Ultrastructure of sporulating cells of Clostridium perfringens type A grown in the presence of raffinose. Canadian Journal of Microbiology 26, 1153-1157.

Labbe, R. G., Reich, R. R. \& Duncan, C. L. (1978). Alteration in ultrastructure and germination of
Clostridium perfringens type A spores following extraction of spore coats. Canadian Journal of Microbiology 24, 1526-1536.

LANE, L. C. (1977). A simple method for stabilizing protein-sulfhydryl groups during SDS gel electrophoresis. Analytical Biochemistry 86, 655-664.

LOFFLER, A. \& LABBE, R. G. (1983). Intracellular proteases during sporulation and enterotoxin formation by Clostridium perfringens type A. Current Microbiology 8, 187-190.

McClane, B. A. \& Strouse, R. J. (1984). Rapid detection of Clostridium perfringens type A enterotoxin by enzyme-linked immunosorbent assay. Journal of Clinical Microbiology 19, 112-115.

MCDONEL, J. L. (1980). Clostridium perfringens toxins (type A, B, C, D, E). Pharmacology and Therapeutics 10, 617-655.

MoIR, A. (1981). Germination properties of a spore coat defective mutant of Bacillus subtilis. Journal of Bacteriology 146, 1106-1116.

Munoz, L., SadaIE, Y. \& DoI, R. H. (1978). Spore coat protein of Bacillus subtilis. Journal of Biological Chemistry 252, 6694-6701.

Nillo, L. (1977). Enterotoxin formation by Clostridium perfringens type A studied by the use of fluorescent antibody. Canadian Journal of Microbiology 23, 908915.

Pandey, N. K. (1980). Spore coat protein of Bacillus subtilis - a summary of recent findings. International Journal of Biochemistry 12, 553-558.

Richardson, M. \& Granum, P. E. (1985). The amino acid sequence of the enterotoxin from Clostridium perfringens type A. FEBS Letters 182, 479-484.

Salinovich, O., Mattice, W. L. \& Blakeney, E. W., $J_{R}$ (1982). Effects of temperature, $\mathrm{pH}$ and detergents on the molecular conformation of the enterotoxin of Clostridium perfringens. Biochimica et biophysica acta 707, 147-153.

SkJelkvale, R. \& DunCan, C. L. (1975). Enterotoxin formation by different toxigenic types of Clostridium perfringens. Infection and Immunity 11, 563-575.

Stelma, G. N., JR, Aronson, A. I. \& Fitz-James, P. C. (1980). A Bacillis cereus mutant defective in spore coat deposition. Journal of General Microbiology 116, 173-185.

Stewart, G. S. A. B. \& Ellar, D. J. (1982). Characterization, purification and synthesis of spore coat protein in Bacillus megaterium KM. Biochemical Journal 202, 231-241.

TsuZUKI, T. \& ANDO, Y. (1985). Chemical studies on the spore coat protein of Clostridium perfringens type A. Agricultural and Biological Chemistry 49, 32213225 .

WALKER, P. D. (1985). Toxigenic spore forming bacteria. In Fundamental and Applied Aspects of Bacterial Spores, pp. 353-369. Edited by G. F. Dring, D. F. Ellar \& G. W. Gould. London: Academic Press. 